\title{
Still retort sterilization process for canned pimiento peppers (Capsicum annuum L.)'
}

\author{
Teresita Rodriguez,2 Horacio Ramírezs and Irvis Y. Pagán
}

\begin{abstract}
Pimiento peppers have a natural $\mathrm{pH}$ of 4.6 to 5.2 and are usually acidified to a pH value lower than 4.6 so that they can be safely processed at atmospheric pressure. The main purpose of acidifying to a $\mathrm{pH}$ lower than 4.6 is to eliminate the potential hazard of Clostridium botulinum growth. The objective of this study was to establish a retort sterilization process that could accelerate the plant canning procedure of pimiento peppers without affecting the canned fruit quality, especially in terms of texture. The study was accomplished with the facilities of the Planta Procesadora de Villalba, in the southern part of the island. The pimientos were placed in $211 \times 300$ tin cans with an acidified (0.4\% citric acid) $2 \%$ brine solution and subjected to three different thermal processes: heating for 3 and 4 minutes at $245^{\circ} \mathrm{F}$, and heating in boiling water for 30 minutes (used as a standard). The $245^{\circ} \mathrm{F}$ thermal processes had an $\mathrm{F}$ value of .03 minutes $(z=10)$ for the 3-minute process, and an $F$ value of 0.16 minutes $(z=10)$ for the 4-minute process. This was calculated by the Patashnik numerical method. The calculated thermal processes, graphically determined by the General Method of Bigelow, was 2.5 minutes for $F=0.03$ and 3.5 minutes for $F=0.16$, both at $245^{\circ} \mathrm{F}$. The recommended thermal process is 4 minutes at $245^{\circ} \mathrm{F}$ with an initial temperature of no less than $170^{\circ} \mathrm{F}$, or 30 minutes in boiling water $\left(212^{\circ} \mathrm{F}\right)$.
\end{abstract}

\section{RESUMEN}

Esterilización en autoclave de pimientos enlatados

Los pimientos morrones (Capsicum annuum) utilizados para enlatarse deben ser grandes, rojos, de piel suave y dulces en sabor. Para obtener "grado A" en textura (según el estándar de identidad federal) las unidades deben ser suaves, pero firmes, y no presentar desintegración aparente. Además deben tener una textura uniforme. Los pimientos tienen un $\mathrm{pH}$ nafural entre 4.6 y 5.2. Por esta razón se acidifican a un $\mathrm{pH}$ de menos de 4.6 para poder enlatarlos a presión atmosférica. Esto garantiza la seguridad del producto y elimina el riesgo potencial de Clostridium botulinum. El procedimiento antes descrito se ha usado desde 1950. El objetivo de este estudio fue establecer un método de esterilización que pudiera acelerar el proceso del enlatado garantizando la seguridad y la calidad, especialmente en términos de textura. El trabajo se hizo en facilidades de la Planta Procesadora de Villalba. Se Ilenaron latas estañadas $211 \times 300$ con pimientos en una solución de salmuera $(2 \%)$ acidificada $(0.4 \%$ de ácido ć́trico). Se sometieron a tres procedimientos termales diferentes: calentándose por 3 y 4 minutos a $245^{\circ} \mathrm{F}$, y calentán-

'Manuscript submitted to Editorial Board 5 October 1990.

"Research Associate, Laboratory of Food Technology.

"Consultant Engineer, Land Authority of Puerto Rico.

${ }^{4}$ Laboratory Technician, Laboratory of Food Technology. 


\begin{abstract}
dose en agua hirviendo por $\mathbf{3 0}$ minutos (usado como estándar). Los procesos térmico a $245^{\circ} \mathrm{F}$ tuvieron unos valores $F$ de 0.03 minutos $(Z=10)$ para el tratamiento de 3 minutos, y de 0.16 minutos $(Z=10)$ para el de 4 minutos. Esto se calculó usando el método numérico de Patashnik. El cálculo para los tratamiento térmicos, determinados gráficamente por el Método General de Bigelow, fue de 2.5 minutos para el $F=0.03$ y 3.5 minutos para el $F=0.16$, ambos a $245^{\circ} \mathrm{F}$. El tratamiento térmico recomendado es de 4 minutos a $245^{\circ} \mathrm{F}$ con una temperatura no menor de $170^{\circ} \mathrm{F}$, o 30 minutos en agua hirviendo $\left(212^{\circ} \mathrm{F}\right)$.
\end{abstract}

\title{
INTRODUCTION
}

Pimiento peppers for canning should be large, deep red, smooth skinned and sweet (11). The seed was first imported from Spain, which still has a vigorous commercial pimiento industry $(5,11)$. In the United States pimientos are successfully grown in many of the Southern states (4). Puerto Rico grows them on the southern coast.

Pimientos, which have a natural $\mathrm{pH}$ of 4.6 to 5.2, are usually acidified to a $\mathrm{pH}$ value lower than 4.6 so that they can be safely processed at atmospheric pressure to prevent undesirable quality changes that may occur during retorting $(5,6,7,11)$. This procedure has been followed since 1950 (6). The main purpose of acidifying to a $\mathrm{pH}$ lower than 4.6 is to eliminate the potential health hazard due to Clostridium botulinum.

The objective of this study was to establish a retort sterilization process that could accelerate the plant canning procedure without affecting the canned product quality, especially in terms of texture.

\section{MATERIALS AND METHODS}

This study was accomplished in the facilities of the Planta Procesadora de Villalba, located on the southern slopes of the central mountains of the island. The hand-picked pimientos coming from Santa Isabel were received in wood boxes and carefully inspected for color and defects. Only sound deep red fruits were accepted and subsequently weighed.

Pimientos were immersed for 105 seconds in a stainless steel tank with a hot $\left(212^{\circ} \mathrm{F}\right) 5 \%$ lye solution to soften their peel. This immersion time should not be increased, because such an increase could result in loss of edible fruit (peeling loss) $(8,9)$. The lye-treated pimientos were then transported on a conveyor belt to a peeler composed of six tubular rotating brushes 3 feet long. After peeling, the pimientos were thoroughly washed with tap water in a stainless steel tank with sprinklers. This was done to remove lye residues on the fruit surface. After this first wash, pimientos were cored manually and fruits were washed again in a second stainless steel tank to remove seeds. Care was taken during this procedure to keep the fruit as whole as possible. Pimientos were then tightly packed by hand into $211 \times 300$ plain tin cans. 
Each can was weighed and corrections were made to reach the desired weight of 5 ounces.

Once the cans were filled, the pimientos were acidified in the can in a $2 \%$ brine solution with $0.4 \%$ citric acid. Because the pimientos were solidly packed at room temperature, an exhaust was necessary in order to obtain an adequate vacuum. For this purpose the open cans were taken across a steam exhaust tunnel for 205 seconds, after which time they were sealed and heat-processed.

TABIE 1.-Heat penetration data of pimierfo yeppers im. $211 \times 3010$ canst

\begin{tabular}{|c|c|c|c|c|c|}
\hline \multicolumn{3}{|c|}{ Process time of 3 minutes } & \multicolumn{3}{|c|}{ Process time of 4 minutes } \\
\hline $\begin{array}{l}\text { Heating time } \\
\text { (minutes) }\end{array}$ & $\begin{array}{c}\text { Temperature } \\
\left({ }^{\circ} \mathrm{F}\right)\end{array}$ & $\mathrm{Fi}$ & $\begin{array}{l}\text { Heating time } \\
\text { (minutes) }\end{array}$ & $\begin{array}{c}\text { Temperature } \\
\left({ }^{\circ} \mathrm{F}\right)\end{array}$ & $\mathrm{Fi}$ \\
\hline IT & 141.3 & 0 & IT & 143.1 & 0 \\
\hline 0.0 & 140.9 & 0 & 0.0 & 142.9 & 0 \\
\hline 0.5 & 140.5 & 0 & 0.5 & 142.6 & 0 \\
\hline 1.0 & 140.3 & 0 & 1.0 & 141.5 & 0 \\
\hline 1.5 & 140.4 & 0 & 1.5 & 142.7 & 0 \\
\hline 2.0 & 142.6 & 0 & 2.0 & 155.4 & 0 \\
\hline $2 . \overline{0}$ & 148.9 & 0 & 2.5 & 167.4 & $4.62 \times 10^{\prime \prime}$ \\
\hline 3.0 & 157.3 & $4.86 \times 10^{-111}$ & 3.0 & 177.5 & $4.88 \times 10^{*}$ \\
\hline 3.5 & 167.8 & $5.19 \times 10^{-9}$ & 3.5 & 187.3 & $4.69 \times 10^{-}$ \\
\hline 4.0 & 179.3 & $7.21 \times 10^{-\infty}$ & 4.0 & 194.1 & $2.46 \times 10^{\circ}$ \\
\hline 4.5 & 187.2 & $4.82 \times 10^{-}-$ & 4.5 & 198.9 & $8.17 \times 10^{4}$ \\
\hline 5.0 & 193.2 & $2.07 \times 10^{-s i}$ & 5.0 & 203.1 & $2.23 \times 10=$ \\
\hline 5.5 & 197.9 & $6.53 \times 10^{-5}$ & 5.5 & 206.6 & $5.23 \times 10=$ \\
\hline 6.0 & 201.5 & $1.60 \times 10^{-3}$ & 6.0 & 209.2 & $1.02 \times 10^{1}$ \\
\hline 6.5 & 204.4 & $3.29 \times 10^{-i}$ & 6.5 & 211.2 & $1.70 \times 10^{4}$ \\
\hline 7.0 & 207.1 & $6.23 \times 10^{\mathrm{s}}$ & 7.0 & 213.1 & $2.66 \times 10^{1}$ \\
\hline 7.5 & 208.9 & $1.02 \times 10^{-4}$ & 7.5 & 214.3 & $3.74 \times 104$ \\
\hline 8.0 & 210.9 & $1.59 \times 10^{+4}$ & 8.0 & 215.6 & $5.00 \times 10^{\prime}$ \\
\hline 8.5 & 212.3 & $2.32 \times 10^{4}$ & 8.5 & 216.4 & $6.32 \times 10^{\prime}$ \\
\hline 9.0 & 213.6 & $3.15 \times 10^{-4}$ & 9.0 & 217.2 & $7.60 \times 10^{1}$ \\
\hline 9.5 & 214.5 & $4.04 \times 10^{4}$ & 9.5 & 217.7 & $8.80 \times 10^{\prime}$ \\
\hline 10.0 & 215.8 & $5.23 \times 10^{-i}$ & 10.0 & 218.8 & $1.06 \times 10^{:}$ \\
\hline 10.5 & 216.6 & $6.62 \times 10^{+}$ & 10.5 & 220.6 & $1.51 \times 10^{a}$ \\
\hline 11.0 & 218.9 & $9.75 \times 10^{-1}$ & 11.0 & 223.4 & $2.64 \times 10^{3}$ \\
\hline 11.5 & 221.6 & $1.76 \times 10^{-3}$ & 11.5 & 226.0 & $4.88 \times 10:$ \\
\hline 12.0 & 224.1 & $3.17 \times 10^{-11}$ & 12.0 & 228.4 & $8.62 \times 10^{*}$ \\
\hline 12.5 & 227.0 & $5.99 \times 10^{*}$ & 12.5 & 230.8 & $1.50 \times 10^{2}$ \\
\hline \multirow[t]{4}{*}{13.0} & 229.4 & $1.08 \times 10^{-2}$ & 13.0 & 232.8 & $2.46 \times 10=$ \\
\hline & & $F_{245}=0.03$ & 13.5 & 234.7 & $3.84 \times 10^{z}$ \\
\hline & & & 14.0 & 236.8 & $6.12 \times 10^{-2}$ \\
\hline & & & & & $F_{245}=0.16$ \\
\hline
\end{tabular}

'Come-up time: 10 minutes. Retort temperature: $245^{\circ} \mathrm{F}\left(118.3^{\circ} \mathrm{C}\right)$. 
The heat sterilization processes were determined by a Kaye Digi 4M System (Bedford, MA) ${ }^{5}$ to record processing temperatures and time. This included a cold spot determination and two heat penetration studies for each of the 3 - and 4-minute thermal processes at $245^{\circ} \mathrm{F}\left(118.3^{\circ} \mathrm{C}\right)$. An additional cold spot determination was performed in the 30 -minute thermal process in boiling water (used as a standard).

The cold spot (slowest heating point inside the can) determination was done with Ecklund T-type molded (plastic) thermocouples $15 / 16^{\prime \prime}$ long positioned at four different locations along the can: $3 / 4^{\prime \prime}, 1^{\prime \prime}, 11 / 4^{\prime \prime}$ and $11 / 2^{\prime \prime}$ from the bottom. The heat penetration study used the same type of thermocouples, all positioned at the same location, specifically in the cold spot determined previously. To calculate the sterilization process, a $z$ (the number of Farenheit degrees required for the thermal destruction curve to traverse one logarithmic cycle) value of 10 was chosen. The sterilization value of the process in minutes ( $F$ value) and the strerilization process time were calculated by graphic and numerical methods $(1,10,12,13)$.

Determination of $\mathrm{pH}$ values was performed with a Beckman $\mathrm{pHI} 71$ meter (Fullerton, California) by the glass electrode method (3). For microbiological analyses, malt extract and acid broth tubes incubated at $32^{\circ} \mathrm{C}\left(89.6^{\circ} \mathrm{F}\right)$ and $55^{\circ} \mathrm{C}\left(131^{\circ} \mathrm{F}\right)$ for 96 and 46 hours, respectively, were used to detect microbial populations capable of growing in acid canned foods. These measurements were accomplished after two weeks of elaboration.

The following flow diagram illustrates all processing steps in pimiento canning.

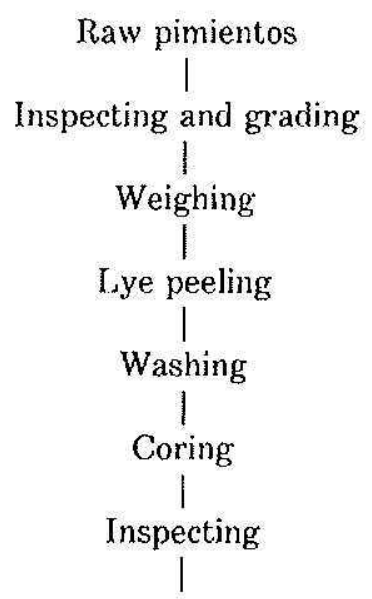

Trade names in this publication are used only to provide specific information. Mention of a trade name does not constitute a warranty of equipment of materials by the Agricultural Experiment Station of the University of Puerto Rico, nor is this mention a statement of preference over the equipment or materials. 


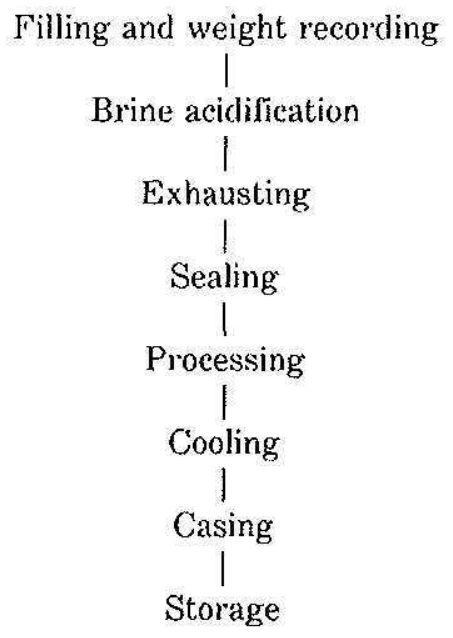

\section{RESULTS AND DISCUSSION}

The cold spot was determined to be at $11 / 2^{\prime \prime}$ from the bottom of the can, at the geometrical center. This was for both the steam under pressure process $\left(245^{\circ} \mathrm{F}\right)$ and for the boiling water process. The heating data of the slowest heating can was used as the basis for calculating the sterilizing value ( $\mathrm{F}$ value) and process time (Tp) in minutes (table 1 ). Average values were not used since it is the pathogenic and spoilage microorganisms present in the slowest heating container that must be destroyed through the calculated thermal process.

The sterilization value, or the process total lethality value $\mathrm{F}$, was calculated for the slowest heating can. The lethal rate figures can be plotted against time to obtain a lethal rate curve. Since the vertical distance on this curve at each minute represents the $\mathrm{F}$ value effective at the minute, it follows that the total sterilizing value is equal to the sum of all the vertical distances for every minute of the process. The sterilizing value then is proportional to the area under the curve. The mathematical expression for this value is

$$
F=\Delta t \times \Sigma I_{i}
$$

where $L_{i}$ is the lethal rate figure in minutes and is defined:

$$
\mathrm{L}_{\mathrm{i}}=\operatorname{antilog}\left(\mathrm{T}-\mathrm{T}_{\mathrm{red}} \mathrm{Z} \mathrm{Z}\right)
$$

where, $T$ is a given temperature at a given time; $T_{\text {ref }}$ is the reference temperature $\left(245^{\circ} \mathrm{F}\right)$; and $\mathrm{Z}$ is the number of Farenheit degrees required for the thermal destruction curve to traverse one log cycle (in this case this value is 10 ). Using the above mentioned equation, the calculated $F$ value for process time of 3 minues was 0.03 minutes, and for process time of 4 minutes was 0.16 minutes.

The process time $(\mathrm{Tp})$ is defined as the time in which the area under the heating curve is equal to one, or the time required for the coldest 
spot to receive one sterilizing effect. The destruction rate per minute of an organism at a given temperature $(\mathrm{T})$ in a process is the reciprocal time $(1 / \mathrm{Tp})$ in minutes required to destroy the organisms at that temperature. The mathematical expression for this is

$$
1 / \mathrm{Tp}=[\mathrm{F} \times \text { antilog }(245-\mathrm{T} / \mathrm{Z})]^{-1}
$$
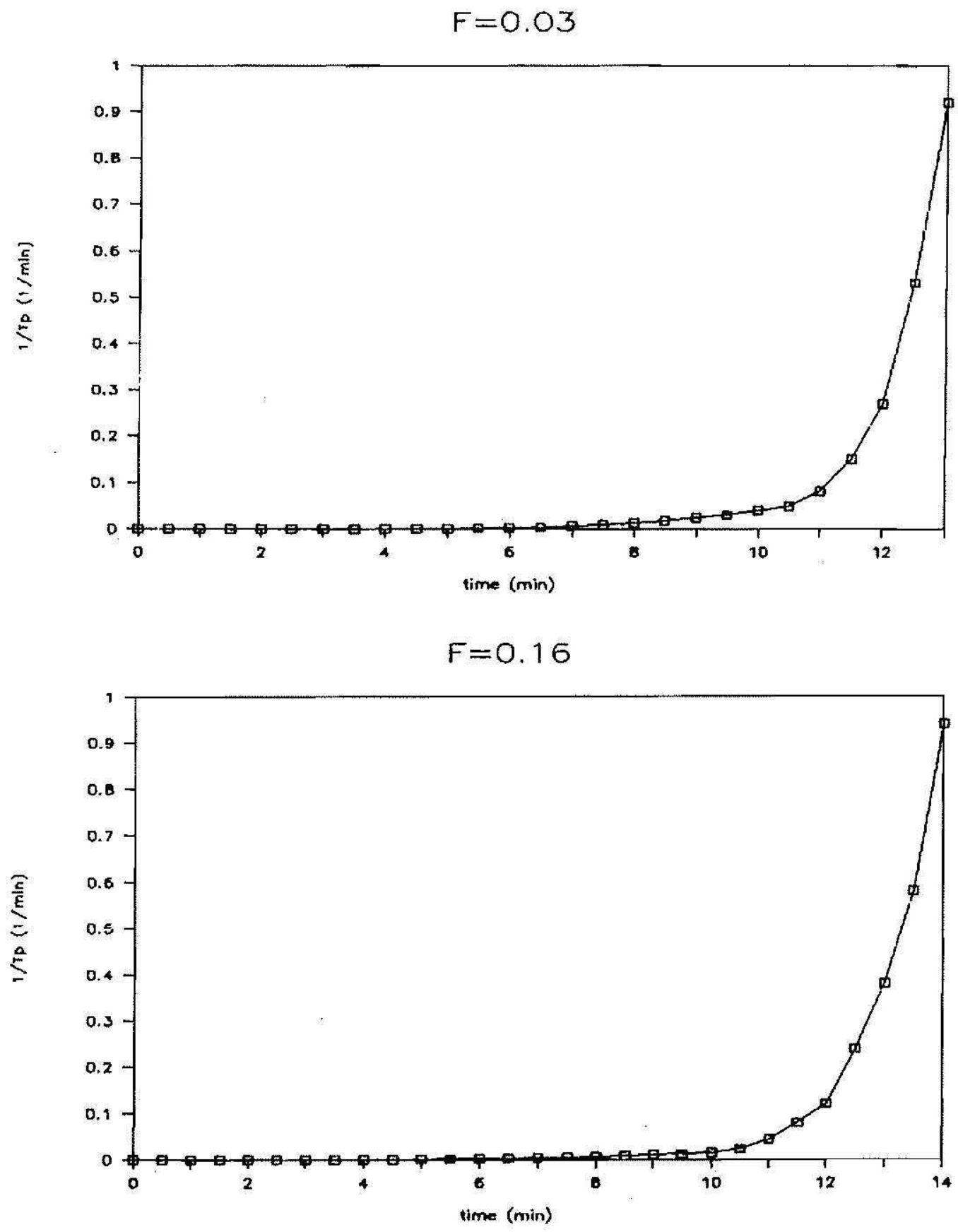

Fig. 1. $-1 / \mathrm{Tp}$ vs time curves of pimiento peppers in $211 \times 300$ cans. 
The graph plotted will be $1 / \mathrm{Tp}$ versus time and $\mathrm{Tp}$ will be determined so that the area under the curve will be equal to one (fig. 1). The calculated process time following this procedure was 2.5 minutes for $\mathrm{F}=0.03 \mathrm{mi}$ nutes, and 3.5 minutes for $\mathrm{F}=0.16$ minutes.

Obtaining accurate data regarding the heating or cooling of a food in a container is extremely important to determine an accurate time and temperature for product sterilization. There are many factors influencing the rate of heat penetration: process (retort) temperature, size and shape of container, fill-in weight, initial product temperature and the nature of the product, among others (11). Therefore, changes in any of these parameters will affect the value of the calculated sterilization process.

The sterilization process recommended for canning peppers in $211 \times$ 300 cans, is 4 minutes at $245^{\circ} \mathrm{F}\left(118.3^{\circ} \mathrm{C}\right)$ with an initial temperature of no less than $170^{\circ} \mathrm{F}\left(76.7^{\circ} \mathrm{C}\right)$. This process time, although greater than that calculated for the $F=0.03$ minutes, provides an additional safety margin for this type of product and at the same time is not detrimental to the desired texture of the peppers. The peppers thus processed met the required specifications (tenderness, texture and firmness of the unit and the condition and thickness of the flesh) as stated in the USDA-Grade Standards for "Grade A" (2). Also, the canned pimiento peppers can be processed at atmospheric pressure in boiling water for 30 minutes as stated in the literature (4).

The $\mathrm{pH}$ profile of the canned pimientos ranged from 3.60 to 3.87 . Microbiological analyses showed that the product was free from organisms capable of growing in it (data not presented). These evaluations were performed to check the safety of the three different thermal processes used with the canned pimientos. Safety was thus confirmed through the results obtained.

\section{LITERATURE CITED}

1. American Can Company Technical Service, 1967. Calculation of Processes for Canned Foods, American Can Co., Barrington, Illinois.

2. Anonymous, 1987. The Almanac of the Canning. Freezing, Preserving Industries, Edward E. Judge and Sons, Inc., Westminster, MD.

3. A.O.A.C., 1980. "Official Methods of Analysis," 13th ed. Association of Official Analytical Chemists, D.C.

4. Cruess, W. V., 1948. Commercial Fruit and Vegetable Products, 3rd ed. McGraw-Hill Book Company, Inc., New Xork.

5. Feria, M. A. and E. Hernández, 1972. Flora típica de conservas de pimientos alteradas. Tiempo de destrucción térmica. Rev. Agroquim. Tecnol. Alim. 12 (2): 315-18.

6. Flora, L. F., E. K. Heaton and A. L. Shewfelt, 1978. Evaluation of factors influencing variability of acidified canned pimientos. J. Food Sci. 43: 415-19.

7. - and E. K. Heaton, 1979. Processing factors affecting acidification of canned pimiento peppers. J. Food Sci. 44 (5): 1498-500.

8. Floros, J. D., H. Y. Wetzstein and M. S. Chinnan, 1987. Chemical $(\mathrm{NaOH})$ peeling as viewed by scanning electron microscopy: pimiento peppers as a case of study. $J$. Food Sci. 53 (5): 1312-316. 
9. and M. S. Chinnan, 1988. Seven factor response surface optimization of a doublestage lye $(\mathrm{NaOH})$ peeling process for pimiento peppers. J. Food Sci. 53 (2): $631-37$.

10. Institute of Food Technologists, 1978. Introduction to the Fundamentals of Thermal Processing, Chicago, Illinois.

11. Jópez, A., 1981. A Complete Course in Cannning: Book II-Processing Procedures for Canned Food Products, 11th ed. The Canning Trade, Baltimore, Maryland.

12. Stumbo, C. R., 1973. Thermobacteriology in Food Processing, 2nd ed., Academic Press, New York and London.

13. - K. S. Puroit, T. V. Ramakrishnan, D. A. Evans and F. J. Francis, 1983. CRC Handbook of Lethality Guides for Low-Acid Canned Foods, CRC Press, Inc., Boca Raton, Florida. 